Proc. Estonian Acad. Sci. Geol., 1997, 46, 2, 75-92

\title{
HOLOCENE VEGETATION AND CLIMATIC CHANGE ON THE HAANJA HEIGHTS, SE ESTONIA
}

\author{
Leili SAARSE and Raivo RAJAMÄE
}

Institute of Geology, Estonia Blvd 7, EE-0001 Tallinn, Estonia; e-mail: saarse@gi.ee

Received 19 February 1997, accepted 10 April 1997

\begin{abstract}
The development of forests on the Haanja Heights has been controlled by external factors, including climate, soils, hydrology, and human impact. The sediment sequence from Lake Kirikumäe, which covers about 12000 years, records the vegetation history throughout the Late Glacial and Holocene. In the Allerød, woodland tundra with sparse birch and willow was established. Grass-shrub tundra in the Younger Dryas was replaced by birch forest in the Pre-Boreal. During the Holocene two major shifts in vegetation dynamics occurred: the first about $8500 \mathrm{BP}$ with a sharp decline in Betula-Pinus forest and development of broad-leaved forest, and the second about 3500 BP, with a decline in broad-leaved forest and regeneration of Pinus-Betula forest with a high share of Picea. The climate modelling, based on pollen record and lake-level changes, suggest cold, severe climate with low precipitation values in the early Pre-Boreal. Between 9500-8500 BP the climate was rather stable. The lake level first rose, then stabilized, and finally dropped. The sharp climate amelioration in the late Boreal together with the humidity increase resulted in a lake-level rise. The decreased precipitation and rather high summer temperatures, increased evapotranspiration, and reduced water balance are characteristic of the Sub-Boreal. Since 3500 BP, the climate deteriorated and mixed coniferous forest started to dominate. Several small climatic fluctuations, including the Little Ice Age cooling, have been traced by modelling.
\end{abstract}

Key words: pollen, radiocarbon dates, lake-level changes, climate reconstructions.

\section{INTRODUCTION}

Several modern Holocene pollen diagrams from lakes of northern and western Estonia have been published during the recent years, but only few pollen diagrams from the Haanja Heights are available (Pirrus, 1969; Sarv, 1983; Mäemets, 1983, 1986; Punning et al., 1995; Ilves \& Mäemets, 1987). Therefore, due to the discovery of the bottommost layer of minerotrophic peat in lakes Punsu and Kõrbjärv, the lakes in the surroundings of Kirikumäe were selected for more detailed biostratigraphical investigation. The primary objective of this study is to 
describe the forest dynamics, reconstruct the trend of lake-level changes and climate variables, and adjust the chronology of the local palaeoecological events. Lakes Kirikumäe, Punsu, and Kõrbjärv were preferred for the reason that their bottom deposits are highly organic and peat occurs below gyttja in Punsu and Kõrbjärv. This study is a part of the research project "Postglacial natural and anthropogenic changes in Estonia".

\section{DESCRIPTION OF THE SITE}

Lake Kirikumäe $\left(57^{\circ} 40^{\prime} \mathrm{N}, 27^{\circ} 15^{\prime} \mathrm{E}\right)$, together with five small neighbouring lakes (Punsu, Kõrbjärv, Linajärv, Pedeja, and Kirbujärv), is situated in the southeastern part of the Haanja Heights, about $5 \mathrm{~km}$ south of the settlement of Vastseliina and $25 \mathrm{~km}$ southeast of the town of Võru, in the hilly dead-ice topography (Fig. 1). The lake is surrounded by bog in the west and south, moraine hills in the north and by an esker ridge in the east. The mineral bottom of the lake is uneven and an underwater ridge subdivides it into the shallower western and the deeper eastern part. The ridge continues in the paludified southernmost lake basin.

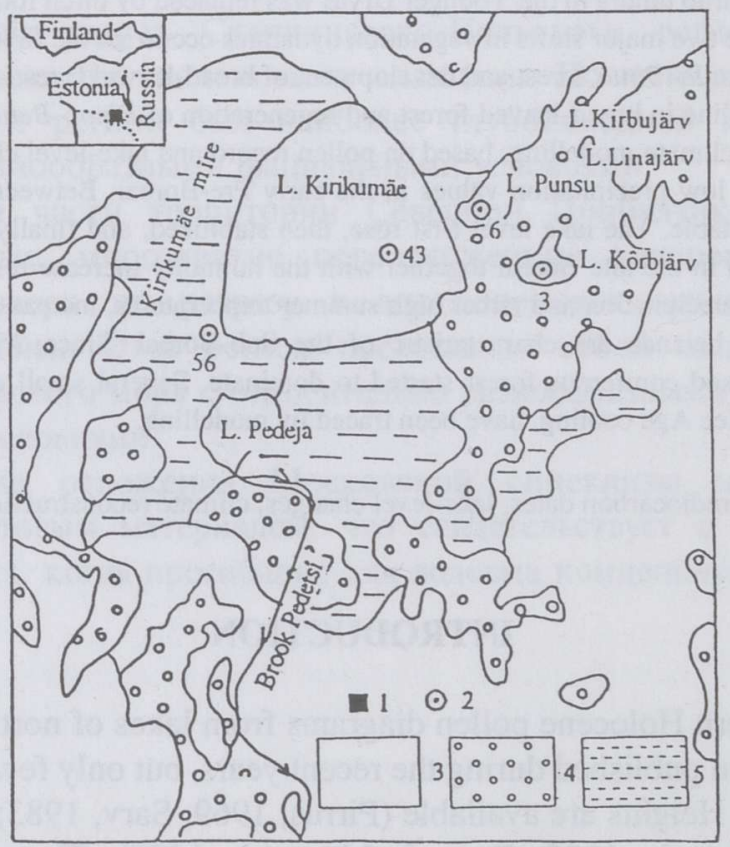

Fig. 1. Location of the studied lakes and the main cores. Legend: 1 , study area; 2, studied cores; 3 , field; 4 , forest; 5 , mire. 
Kirikumäe is a medium-sized semidystrophic lake with a surface area of 61.4 ha at an elevation of $183 \mathrm{~m}$ a.s.l. In the Late Glacial the lake was about 2-3 times as large as at present. The length of the lake is about $1 \mathrm{~km}$, width $0.9 \mathrm{~km}$, maximum water depth $3.5 \mathrm{~m}$, and mean depth $2.8 \mathrm{~m}$ (Eesti järved, 1968). It has a temporal (during high-water periods) inflow from Lake Punsu and an outflow via a ditch to Lake Pedeja (Fig. 1). Kirikumäe is mostly fed by precipitation and, as a result, its water is poor in mineral compounds $\left(2-6 \mathrm{mg} / \mathrm{l} \mathrm{HCO}_{3}\right)$ and slightly acid (pH 5.3-6.0; Mäemets, 1977). The catchment area of the lake, about 200 ha, is covered by a paludified pine-spruce forest, raised bog, and fields. Punsu has a surface area of 3.2 ha and Kõrbjärv about 2.2 ha. Both lakes are shallow, with the water depth less than $2 \mathrm{~m}$. They are also surrounded by paludified pine-spruce forest and small marginal fens.

\section{METHODS}

A 0.5 -m-long Russian peat corer was used to get the transects through the bog and transects across the lake sediments. The depth of the substratum (till, silt or sand) was always determined. The corings on the lake were operated from an anchored raft. Surface samples were taken by a piston corer. Cores No. 56 at the marginal and No. 43 in the eastern part of Lake Kirikumäe, and No. 6 in Lake Punsu were subjected to pollen analysis. For this purpose the wet sediment, taken after every 5 or $10 \mathrm{~cm}$, was subsampled into $1-\mathrm{cm}$ pieces. The samples were boiled in $10 \% \mathrm{KOH}$, coarse mineral particles were removed by decantation, plant fragments by sieving through a $0.25-\mathrm{mm}$ sieve. Fine mineral particles were separated by $\mathrm{KJ}+\mathrm{CdJ}_{2}$ and then treated by the standard acetolysis technique. The basis for the percentage calculations of the data is the sum of arboreal (AP) and nonarboreal (NAP) pollen. The pollen diagram was plotted with TILIA and TILIA graph programs (Grimm, 1992). The vegetation history is revealed from pollen records, changes in the water balance inferred from levelled terraces, sediment lithology, sediment limit, and aquatic pollen, climatic reconstructions are based on Appolinaire program by J. Guiot (Marseille, France). The organic content was estimated as loss on ignition at $550^{\circ} \mathrm{C}$ for four hours.

\section{RESULTS AND DISCUSSION}

\section{Lithostratigraphy of bottom deposits}

Mineral bottom deposits of Lake Kirikumäe are till, laminated silt, in some places sand, and compact silt with plant fragments. The thickness of the late glacial silty deposits is about $120-150 \mathrm{~cm}$ in the profundal part of the lake, but they are missing in the narrow northern and eastern littoral zone. The same deposits occur in deeper hollows of the overgrown southern and western parts of 
the basin. The late glacial beds hardly level the undulated bottom topography and so the gyttja is found at different elevations. The lowest jelly algal gyttja with a thickness of about $50-100 \mathrm{~cm}$ is covered by a layer of fine gyttja, the thickness of which ranges from some centimetres in the littoral zone up to $450 \mathrm{~cm}$ in the hollows. In the overgrown area it is overlain by peat. The Holocene organogeneous deposits are at their thickest (up to $10 \mathrm{~m}$ ) in the southern part of the basin.

Sediment lithology in Punsu and Kõrbjärv differs from that of Kirikumäe. The basins of the former two were cut into glaciofluvial sands and Late Glacial laminated silt is commonly absent. Only in the central part of Punsu a thin layer of silt with organic fragments has been determined. In both lakes two buried peat layers separated by gyttja have been found. The basal peat with a thickness of $2 \mathrm{~cm}$ in Punsu (at a depth of $440-442 \mathrm{~cm}$ ), and $20 \mathrm{~cm}$ in Kõrbjärv is located in the deepest part of the lakes. The uppermost peat layer in Punsu is $50 \mathrm{~cm}$, and in Kõrbjärv about $110 \mathrm{~cm}$ thick. The total thickness of Holocene deposits in the central part of Kõrbjärv reaches $715 \mathrm{~cm}$. Sediment lithology of Kirikumäe and Punsu is indicated on the pollen diagrams, in Kõrbjärv it is described as follows: $0-130 \mathrm{~cm}$ of water, $130-370 \mathrm{~cm}$ of gyttja, $370-460 \mathrm{~cm}$ of gyttja with plant remains, $460-500 \mathrm{~cm}$ of peat, $500-650 \mathrm{~cm}$ of gyttja, $650-725 \mathrm{~cm}$ of gyttja, $725-845 \mathrm{~cm}$ of peat, $845-850 \mathrm{~cm}$ of sand.

\section{Sediment composition}

The grain size composition of compact silt, laminated silt, and till in Lake Kirikumäe is shown in Table 1 . The grain size composition of differently graded beds is rather similar due to their common source - the till. Their fine matrix material has been washed out and resedimented. The till displays high values of coarse fraction (Table 1).

Table 1

Grain size composition of minerogenic deposits of Lake Kirikumäe, \% (core 57)

\begin{tabular}{lr|l|l|l|l|l|l|l}
\hline Depth, cm & $>0.1$ & $\begin{array}{l}0.1- \\
0.05\end{array}$ & $\begin{array}{l}0.05- \\
0.01\end{array}$ & $\begin{array}{l}0.01- \\
0.005\end{array}$ & $\begin{array}{l}0.005- \\
0.002\end{array}$ & $\begin{array}{l}0.002- \\
0.001\end{array}$ & $<0.001$ & Sediment \\
\hline $280-300$ & 5.0 & 6.8 & 76.0 & 1.9 & 3.8 & 1.1 & 5.0 & Clayey silt (compact) \\
$300-325$ & 0.8 & 4.3 & 46.0 & 4.2 & 29.5 & 4.6 & 10.6 & Silty clay (compact) \\
$325-350$ & 2.1 & 5.0 & 54.4 & 17.3 & 6.0 & 10.3 & 4.9 & Clay silt (laminated) \\
$350-360$ & 3.8 & 6.8 & 53.2 & 18.4 & 3.8 & 5.1 & 8.9 & Clay silt (laminated) \\
$360-370$ & 56.9 & 7.9 & 17.3 & 6.5 & 4.2 & 3.3 & 3.9 & Stony silt (till)
\end{tabular}


Gyttja in Kirikumäe is rich in organic matter (82-94\%). The carbonate content is commonly less than 1-2\% with maximum values of $6 \%$ in the bottommost part of gyttja. The minerogenic deposits show an increased $\mathrm{CaCO}_{3}$ content, which is $9.7-10.6 \%$ in the massive and $13.5-16.1 \%$ in the laminated silt. Terrigenous compounds have two remarkable peaks in gyttja: the first increase at a depth of $380-390 \mathrm{~cm}$ and the second in the uppermost part of the sequence.

The deposits of Lake Punsu are also characterized by a high organic matter content (75-92\%) with a similar to Kirikumäe trend to change. The organic matter content displays greatest variations in the lowermost gyttja and minerotrophic peat, decreasing to $59 \%$ at a depth of $425 \mathrm{~cm}$ and to $44 \%$ at a depth of $435 \mathrm{~cm}$.

\section{Radiocarbon dates}

Four cores were subject to radiocarbon dating. The results are presented in Table 2.

Radiocarbon dates on Kirikumäe and Punsu were obtained on bulk organic material except for the uppermost samples. These were sieved to get the coarse fraction above $1 \mathrm{~mm}$ representing mainly the macroremains of terrestrial plants. It was intended to date granulometric fractions separately assuming that there might be an age difference due to the erosion of older sediments released by the drainage activity in the last centuries. The amount of coarse fractions of all treated samples turned out too small (less than $1 \%$ of the total sample mass) to enable the dating by conventional technique.

The radiocarbon data obtained on Kirikumäe suggests an age of about one thousand years for subsurface samples (Table 2). It may be caused by ageing of data due to geochemical reasons, lack of sedimentation over the last millennium, reworking of the uppermost sediments by wave action and/or contamination by older humic compounds from the surrounding mire. To elucidate which of those alternative reasons is prevailing is a problem of principal importance while elaborating the chronology for these sediments.

A reliable way to establish the continuity of recent sedimentation in a lake is to determine the ${ }^{210} \mathrm{~Pb}$ content in sediment. Thus, if the sedimentation has not taken place during last centuries, we cannot find any remarkable concentration of ${ }^{210} \mathrm{~Pb}$ in subsurface sediments. Measurements of this isotope, performed in the Institute of Ecology, showed the following concentrations. For the depth interval of $0-10 \mathrm{~cm}$ from the surface the ${ }^{210} \mathrm{~Pb}$ content was $22.0 \pm 1.0 \mathrm{pCi} / \mathrm{g}$ and for the depth of $10-20 \mathrm{~cm} 9.4 \pm 0.5 \mathrm{pCi} / \mathrm{g}$. These values correspond to the mean measure determined for Estonian lakes with a sedimentation rate of 1-2 mm/yr (Rajamäe \& Varvas, 1990). Thus, the ${ }^{210} \mathrm{~Pb}$ data confirm the presence of permanent sedimentation in Kirikumäe. Consequently, the apparent radiocarbon age of upper layers is caused by some other factor mentioned above. 
Radiocarbon dates from lakes Kirikumäe, Punsu, and Kõrbjärv

\begin{tabular}{|l|l|l|l}
\hline Laboratory code & Depth, $\mathrm{cm}$ & Age, ${ }^{14} \mathrm{C} \mathrm{yr}$ & Material \\
\hline
\end{tabular}

Kirikumäe, core 5 (Ilves, 1980a, b)

$\begin{array}{llll}\text { TA-677 } & 450-460 & 2680 \pm 80 & \text { Sphagnum peat, lower limit } \\ \text { TA-678 } & 570-580 & 3210 \pm 70 & \text { Hypnum-Phragmites peat, lower limit } \\ \text { TA-679 } & 780-790 & 8530 \pm 80 & \text { Gyttja, lower limit }\end{array}$

Kirikumäe, core 43 (by R. Rajamäe)

$\begin{array}{llll}\text { Tln-1539 } & 180-190 & 1300 \pm 45 & \text { Sediment surface, gyttja } \\ \text { Tln-1538 } & 190-200 & 1625 \pm 40 & \text { Gyttja } \\ \text { Tln-1639 } & 200-210 & 1610 \pm 60 & \text { Gyttja } \\ \text { Tln-1640 } & 210-220 & 1975 \pm 40 & \text { Gyttja } \\ \text { Tln-1644 } & 220-230 & 2710 \pm 60 & \text { Gyttja } \\ \text { Tln-1648 } & 230-240 & 2865 \pm 80 & \text { Gyttja } \\ \text { Tln-1434 } & 340-350 & 3800 \pm 70 & \text { Gyttja } \\ \text { Tln-1445 } & 490-500 & 6045 \pm 80 & \text { Gyttja } \\ \text { Tln-1446 } & 610-620 & 7695 \pm 105 & \text { Gyttja } \\ \text { Tln-1447 } & 665-670 & 9395 \pm 75 & \text { Gyttja, lower limit }\end{array}$

Punsu, core 6 (by R. Rajamäe)

$\begin{array}{lccl}\text { Tln-1586 } & 130-140 & 145 \pm 60 & \text { Sediment surface, gyttja } \\ \text { Tln-1662 } & 140-150 & 740 \pm 70 & \text { Gyttja } \\ \text { Tln-1657 } & 150-160 & 880 \pm 70 & \text { Gyttja } \\ \text { Tln-1660 } & 160-170 & 815 \pm 75 & \text { Gyttja } \\ \text { Tln-1664 } & 170-180 & 1225 \pm 70 & \text { Gyttja } \\ \text { Tln-1663 } & 180-190 & 1380 \pm 100 & \text { Gyttja } \\ \text { Tln-1582 } & 240-250 & 2970 \pm 90 & \text { Gyttja } \\ \text { Tln-1590 } & 340-350 & 4775 \pm 70 & \text { Algal gyttja, upper limit } \\ \text { Tln-1588 } & 390-400 & 6625 \pm 50 & \text { Buried peat, upper limit } \\ \text { Tln-1589 } & 420-430 & 7220 \pm 65 & \text { Buried peat, lower limit } \\ \text { Tln-1592 } & 430-440 & 7435 \pm 60 & \text { Clayey gyttja, upper limit } \\ \text { Tln-1593 } & 440-450 & 7855 \pm 115 & \text { Clayey gyttja, lower limit }\end{array}$

Kõrbjärv, core 3 (by R. Rajamäe)

$\begin{array}{llll}\text { Tln-1668 } & 735-745 & 8200 \pm 80 & \text { Soluble fraction of gyttja } \\ \text { Tln-1666 } & 735-745 & 8600 \pm 100 & \text { Insoluble fraction of gyttja } \\ \text { Tln-1670 } & 745-750 & 8725 \pm 60 & \text { Buried peat }\end{array}$


A conspicuous trend of $\delta^{13} \mathrm{C}$ values of organic matter obtained for the upper $150 \mathrm{~cm}$ of the sediment layer indicates a remarkable change in the ratio of carbon fluxes into the lake. This means that in the formation of the sedimentary organic matter the atmospheric carbon, as well as that from allochthonous terrestrial material or metabolic $\mathrm{CO}_{2}$ from organic-rich bottom deposits, participated. The last two carbon flows cause ageing of radiocarbon data, which is the case for the upper sediment layer. A decrease in the sedimentation rate from 0.7 to $0.37 \mathrm{~mm} / \mathrm{yr}$ upward in the core suggests a lowering of the trophic level in the lake, but, on the other hand, it shows an increasing allochthonous load into the lake.

Interpolating ${ }^{14} \mathrm{C}$ data on Punsu from a depth of 30 to $66 \mathrm{~cm}$ to the sediment surface, only negligible apparent age is obtained. The few $\delta^{13} \mathrm{C}$ data on Punsu suggest that all the three main carbon sources participated in the formation of organic carbon in sediments. Because of the very small area of the lake, it is possible to suppose the relative importance of littoral and coastal plants in the formation of sediment composition. For chronological purposes we can conclude a good validity of ${ }^{14} \mathrm{C}$ data through the whole sediment core.

\section{Biostratigraphy and chronology}

The pollen diagram of Lake Kirikumäe (Fig. 2) has been divided into eight local pollen assemblage zones (PAZs), those of Kirikumäe mire and Lake Punsu into five and three zones, respectively. The PAZs are mainly described on the basis of AP taxa.

Ki1 ( $860-840 \mathrm{~cm}$, laminated silt) is characterized by a high percentage of Betula (up to $60 \%$ ), moderate or low values of Pinus (20-30\%), Salix, and occasional grains of redeposited Ulmus, Tilia, and Corylus pollen. The NAP percentage is high, 15-20\%, especially Gramineae, Artemisia, Chenopodiaceae, and Cyperaceae. Betula nana reaches 5-10\%. This assemblage is characteristic of the Late Glacial, obviously of the lower part of the Allerød. A poorly developed open woodland tundra, mostly with birch and willow, is suggested.

Ki2 (840-755 cm, laminated silt). High values of Pinus pollen (40-60\%), moderate Betula (10-20\%), and low Picea (1-2\%) are recorded. The Pinus pollen curve has an irregular increase with a short decline in the middle of the PAZ, while the Betula curve rises. NAP pollen reaches $22 \%$. It contains mostly Gramineae, Cyperaceae, Artemisia, and Chenopodiaceae. The Betula nana curve first declines but rises again in the topmost part of the zone. This PAZ corresponds to the Allerød chronozone. The vegetation was characterized by dominant pine and birch with a high share of herbs.

Ki3 (755-685 cm, silt) shows a marked decrease in Pinus and increase in Betula pollen percentages with indicative Picea, Betula nana, and NAP pollen frequencies, especially Gramineae, Cyperaceae, Artemisia, and Chenopodiaceae. 


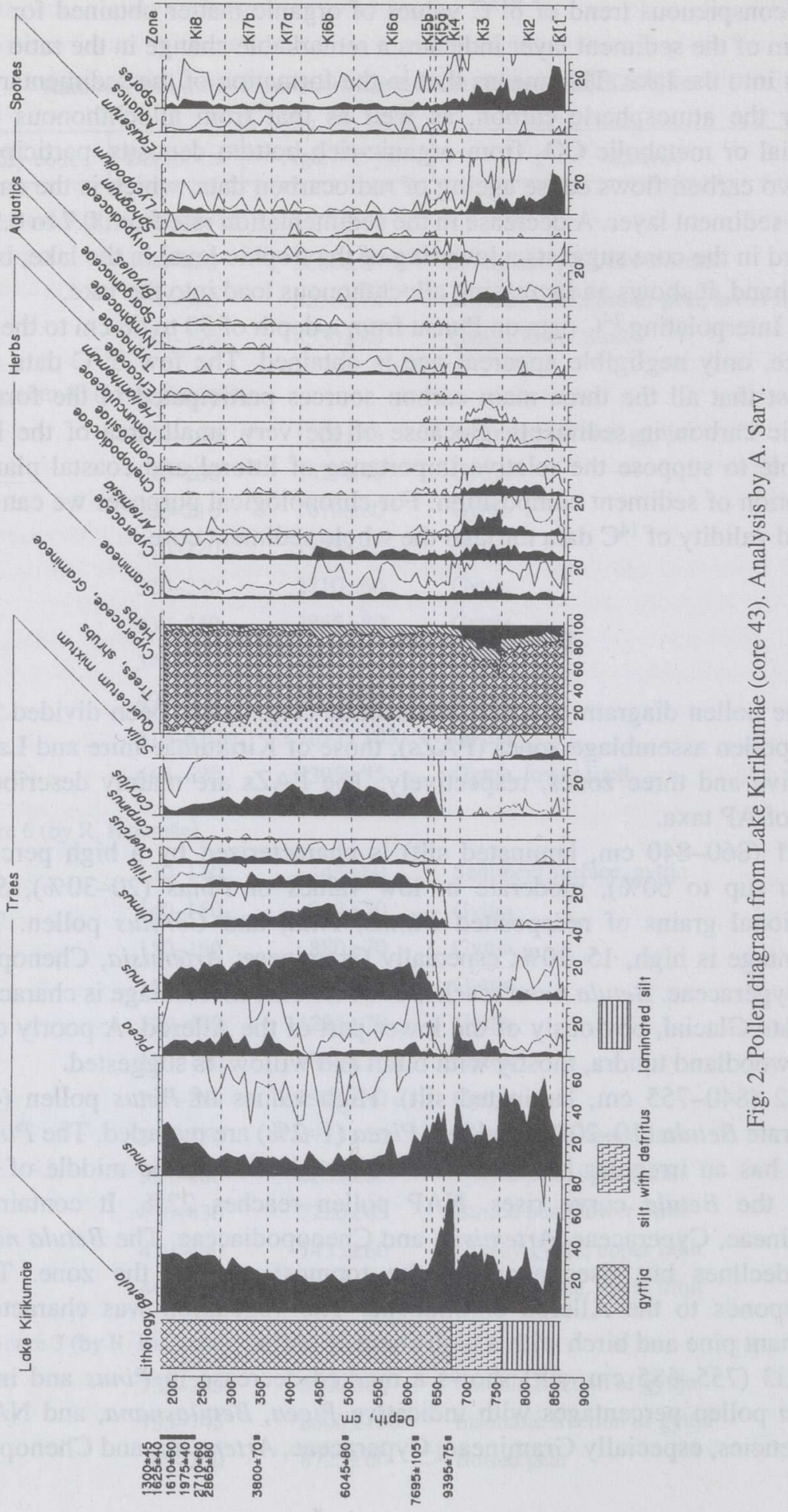


Artemisia is the main taxon to profit from the decline of AP. This PAZ corresponds to the Younger Dryas chronozone, during which grass-shrub tundra with birch, to a lesser extent with pine and spruce (?), prevailed. The arrival and presence of spruce in southeastern Estonia during the Younger Dryas is still open to question (Ilves \& Sarv, 1975; Serebryanny, 1973; Orgla, 1983; etc.). Moe (1970) maintained that Picea pollen values between 5-10\% denote either the presence of considerable numbers of the tree in the area proper or $10-50 \mathrm{~km}$ away. Low Picea pollen values (1-3\%) are due to long transport over a distance of $100 \mathrm{~km}$, and up to $5 \%$ could be transported from a distance of more than $50 \mathrm{~km}$ (Moe, 1970). In the Lake Kirikumäe diagram the Picea pollen amounts to 10$12 \%$, in the Remmeski diagram even to $20 \%$ (Pirrus, 1969). This could mark the presence of spruce on the Haanja Heights already during the Younger Dryas.

$\mathrm{Ki} 4$ (685-655 cm, transition from silt to gyttja). In this PAZ Betula reaches its absolute maximum (70\%), while Pinus pollen has a sharp fall. Gramineae, Cyperaceae, Artemisia, and Chenopodiaceae decrease, Picea and Betula nana pollen disappears. This PAZ ranges into the Pre-Boreal and characterizes as a woodland expansion. Mostly birch forest with open canopy prevailed. Pine was suppressed. At the end of the Pre-Boreal elm also started to colonize the Haanja Heights. Its empirical limit is dated to $9100 \mathrm{BP}$ and rational limit to $8900 \mathrm{BP}$. The Pre-Boreal period did not favour spruce growth. Its pollen is absent or scanty (Ilves \& Mäemets, 1987). Typical late glacial shrubs - Betula nana and Salix were present at the beginning, but disappeared by the end of the period.

Ki5 (655-630 cm, gyttja). This PAZ is subdivided into two subzones. The sudden expansion of Ulmus, dated to $9395 \pm 75 \mathrm{BP}$ and later associated with that of Corylus (from 0 to 13\%), led to a sharp decline in Betula pollen (from 75 to $50 \%)$ in subzone Ki5a $(655-640 \mathrm{~cm})$. Picea pollen reappears. Tilia and Quercus have their absolute limit. Gramineae and Cyperaceae pollen forms continuous curves, the other herbs are present sporadically. This PAZ corresponds to the early Boreal chronozone. Subzone Ki5b $(640-630 \mathrm{~cm})$ is compressed and weakly represented in both Kirikumäe diagrams (Figs. 2,3). Expansion of Ulmus and Corylus continues. Tilia reaches its empiric limit. This zone corresponds to the late Boreal chronozone. During the Boreal the forest composition enriched with alder, hazel, and lime which expanded rapidly together with elm. The hazel immigrated about $8770 \mathrm{BP}$, alder $8650 \mathrm{BP}$, lime about $8300 \mathrm{BP}$. Alnus glutinosa macrofossil finds not far from Kirikumäe, dated to $8640 \pm 55$ BP (TA-651; Punning et al., 1995), indicate the presence of alder. Regeneration of the spruce stands started also in the Boreal. The empirical limit of spruce occurred about $8500 \mathrm{BP}$.

Ki6a (630-500 cm, gyttja) is represented by a reduction in Betula and Pinus pollen, while that of Ulmus, Tilia, Quercus, Corylus, and Alnus increases. There is a small peak in Picea pollen dated to $7695 \pm 105$ BP, which coincides with the decline in Alnus, obviously caused by a lake-level fluctuation. The value of the total AP is high. This pollen composition is characteristic of the early Atlantic chronozone. 
Ki6b (500-410 cm, gyttja). The pollen percentage of broad-leaved trees has increased due to the high but unstable values of Ulmus, Tilia, and Quercus. The share of Corylus and Alnus is also high. The sum of herb pollen is unexpectedly high. This PAZ coincides with the late Atlantic chronozone. The boundary of $\mathrm{Ki} 6 \mathrm{a} / \mathrm{Ki}$ b subzones is dated to $6045 \pm 80 \mathrm{BP}$. During the Atlantic the area of the broad-leaved forest increased rapidly. Dense forest covered the whole of the Haanja Heights. However, compared to the other parts of Estonia, all broadleaved trees culminated here with some delay (Pirrus et al., 1987; Saarse et al., 1990; Saarse \& Königsson, 1992): elm in the late Atlantic, lime in the early SubBoreal, and oak in the late Sub-Boreal.

$\mathrm{Ki} 7$ (410-280 cm, gyttja) is also divided into two subzones. The increase in Picea and Quercus and fall in Ulmus define the lower limit of the Ki7a PAZ. Tilia is still rather high and has a sharp decline in the middle of the Ki7b PAZ. On the transition of subzones $\mathrm{Ki} 7 \mathrm{a} / \mathrm{Ki} 7 \mathrm{~b}$, single grains of Carpinus pollen appeared, dated to $3800 \pm 70 \mathrm{BP}$. These subzones correspond to the early and late SubBoreal chronozone. In the early Sub-Boreal the share of Quercetum mixtum (QM) forest is still high, but it starts to fall in the middle of the late Sub-Boreal. Ulmus decline is registered at about $4300 \mathrm{BP}$, the final decline of Tilia at $3600 \mathrm{BP}$. Birch and spruce forest expanded in the area of their habitat, with some hazel and alder carr around the lake.

Ki8 (280-180 cm, gyttja). Betula pollen dominates, Pinus is subdominant. Ulmus, Tilia, Quercus, and Corylus are constantly present but with low values. The total AP sum is high throughout the PAZ. Thus, the demise of broad-leaved forest occurred at the base of this PAZ. The climatic deterioration together with human activities caused an increase in the birch and pine forests. A second spruce forest expansion in the middle of the PAZ is less obvious due to the consequences of human interference with the landscape. However, the usual anthropogenic indicators are weakly represented in this diagram.

In the marginal core (Fig. 3) the lowermost part of the sequence is compressed and PAZs are not representative, except the uppermost Km8 PAZ, which could be correlated with the Sub-Atlantic chronozone. The pollen spectra of the marginal core differ from the lacustrine one by low Alnus, especially in the uppermost part, a well developed Picea curve, and high percentages of spores (Fig. 3). Unlike the main core (Fig. 2), the Fagus pollen is present since the $\mathrm{Km} 8 \mathrm{~b}$ PAZ, and Ulmus and Tilia pollen has disappeared in the upper part of the Km8c PAZ. In the topmost part of the diagram, the herb pollen curve rises rapidly, Secale cereale pollen appears. This is clearly related to the agricultural activities and could evidence the establishment of now abandoned farms on the southwestern slope of the Lake Kirikumäe basin.

The Lake Punsu pollen diagram starts from the Pu6a PAZ, in which the empiric limit of Alnus, Ulmus, and Tilia appears almost in the same level (Fig. 4), obviously marking a hiatus between silt and clayey gyttja. In zone Pu6b Ulmus has a slight maximum. The share of Tilia pollen is rather high. Betula and Pinus 

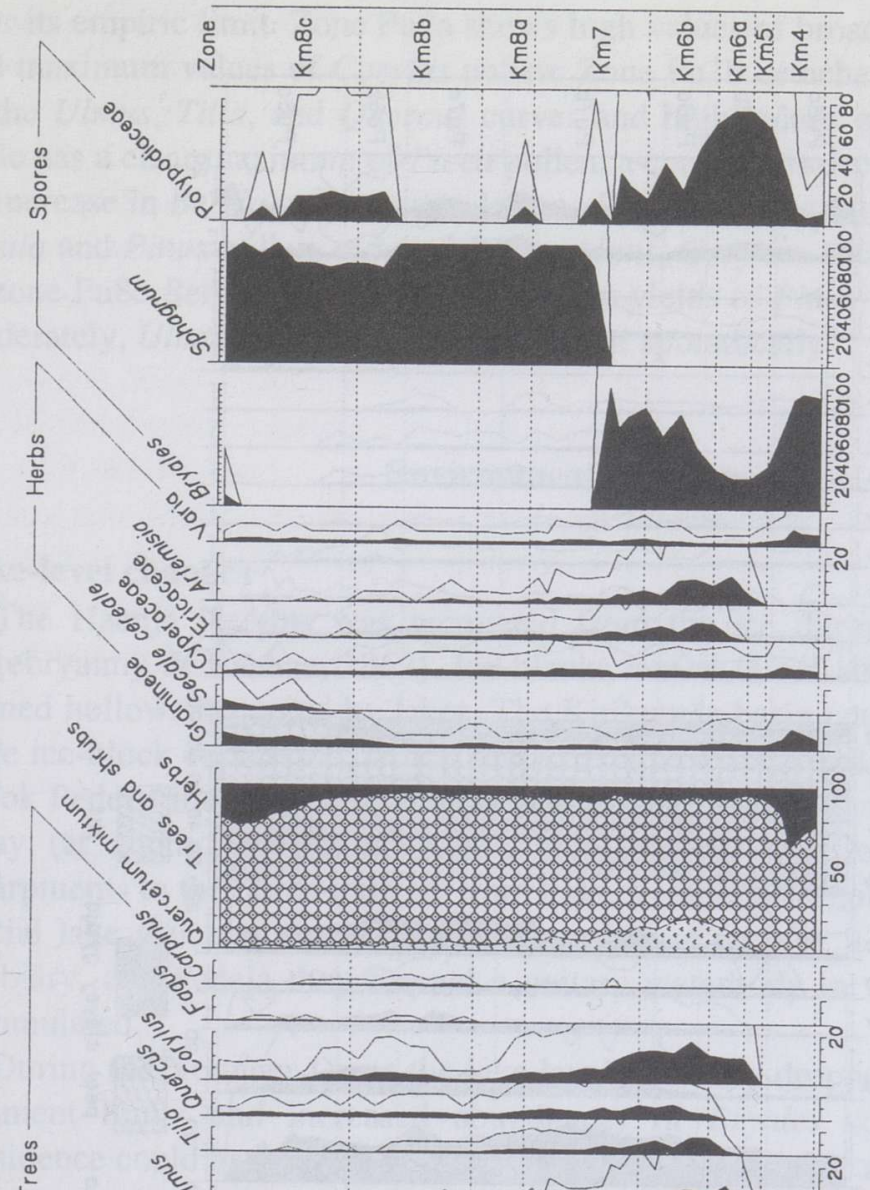

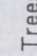
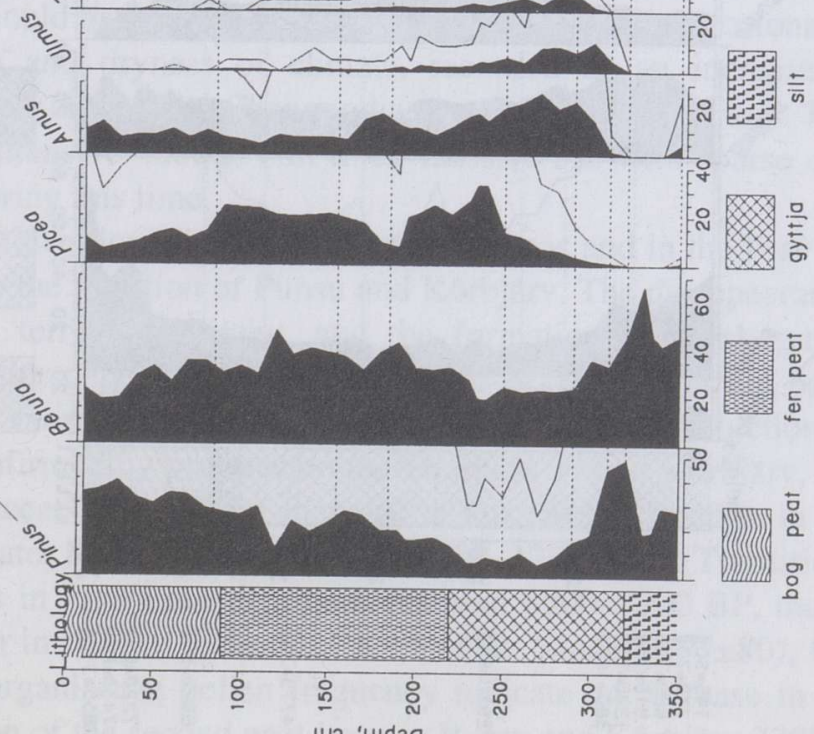

: 


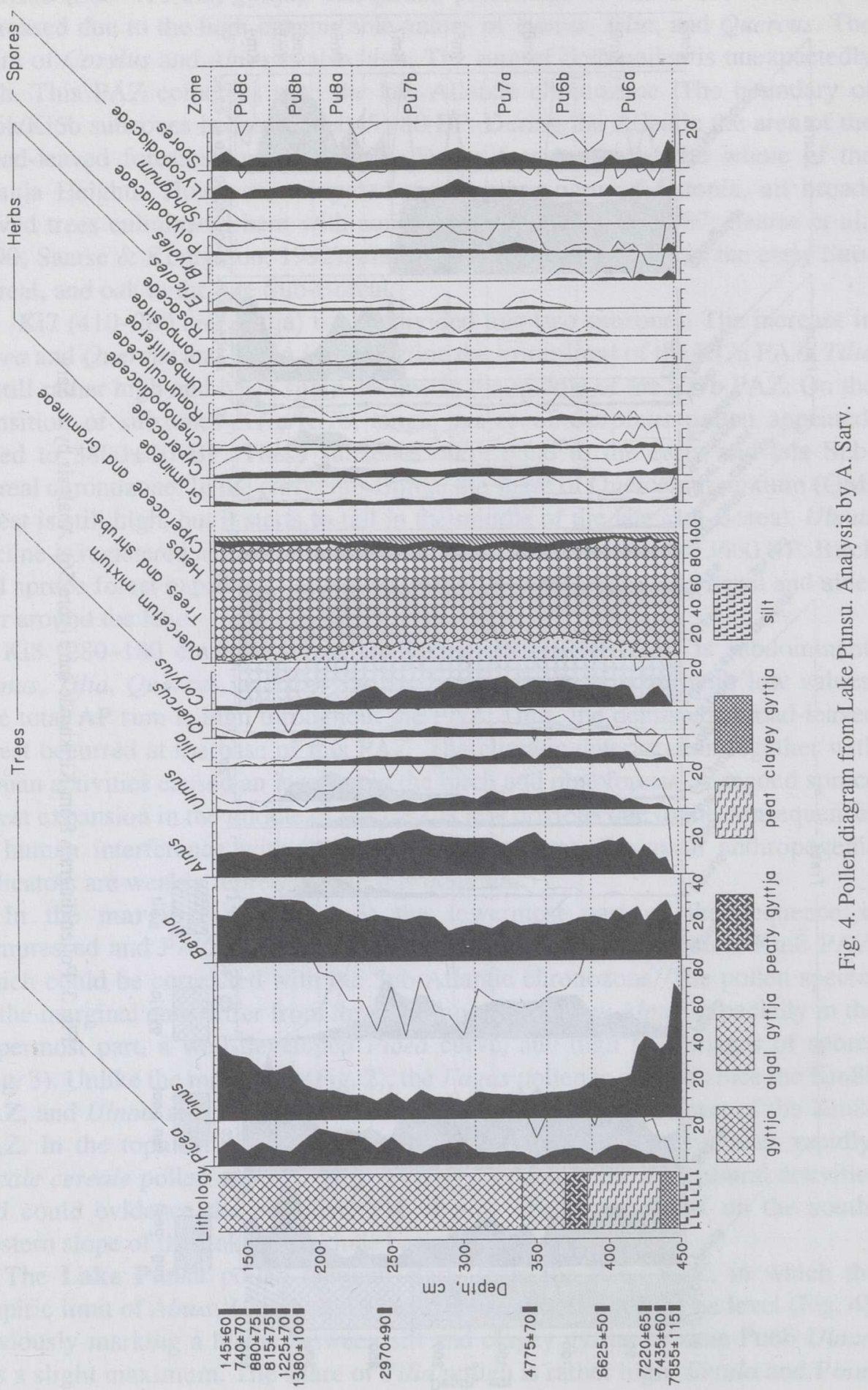


gradually diminish, Picea is present with low unstable values, Quercus pollen is near its empiric limit. Zone Pu7a shows high values of broad-leaved trees, Alnus, and maximum values of Corylus pollen. Zone Pu $7 \mathrm{~b}$ detaches itself by a decrease in the Ulmus, Tilia, and Quercus curves and high values of Alnus pollen. PAZ $\mathrm{Pu} 8 \mathrm{c}$ has a clear maximum of Picea pollen, a continuous decrease in the QM, and an increase in Betula pollen instead. Zone Pu8b is characterized by an increase in Betula and Pinus pollen, reduced Picea, Alnus, Corylus, Ulmus, and Tilia pollen. In zone Pu8c Betula first increases but then yields to Pinus. Alnus is represented moderately, Ulmus, Tilia, and Quercus occur sporadically.

\section{Environmental history}

\section{Lake-level changes}

The Haanja Heights was recovered from the ice during the Oldest Dryas (Serebryanny \& Raukas, 1967). Ice blocks buried in till and gravel melted and formed hollows occupied by lakes. The Kirikumäe basin could have been such a large ice-block depression, which served as a meltwater collector drained via the Brook Pedetsi into the Gauja River. The lake level was about 3-4 m higher than today (at about 185-186 m a.s.l.), revealed from the levelled terraces and escarpments to the north and east from Lake Kirikumäe. Thus, the area of the late glacial lake was about three times larger than at present. Together with Punsu, Kõrbjärv, and Pedeja they formed a unitary waterbody in which laminated silt accumulated.

During the Younger Dryas the lake level evidently dropped to $182 \mathrm{~m}$ a.s.l., as sediment limits and increased abundances of Bryales spores suggest. This subsidence could have been caused by the lowering of the erosional base or by the deterioration and dryness of climate, recorded as an increase in xerophytic species, mainly Artemisia, Chenopodiaceae, and Helianthemum. The soil erosion was rather intensive. About $1 \mathrm{~m}$ thick massive silt with sparse organic detritus deposited during this time.

The lake-level lowering in the Younger Dryas and in the first half of the PreBoreal led to the isolation of Punsu and Kõrbjärv. The disappearance of aquatics, reduction in terrigenous input, and the formation of algal gyttja indicate an increased water depth at the end of the Pre-Boreal and at the beginning of the Boreal. This short-term increase was replaced by a new reduction around 8500 8700 BP confirmed by peat accumulation in Punsu and Kõrbjärv, the appearance of Sparganiaceae and a slight increase in terrigenous fraction in the Kirikumäe sequence. Water level dropped to at least $178-179 \mathrm{~m}$ a.s.l. Transition from peat to lake deposits in Punsu and Kõrbjärv between 8500-7200 BP, the start of gyttja accumulation in deeper hollows of Kirikumäe (since $8530 \pm 80$ ), low Typha and sporadic Sparganiaceae pollen frequency indicate an increase in the lake level. The formation of the second peat layer in Punsu and Kõrbjärv 7200-6600 BP and 
its elevation suggest a new lake-level fall to about $180 \mathrm{~m}$. In the Kirikumäe sequence it is registered as an increase in the total abundance of aquatic pollen, especially Typhaceae. During these low phases Kirikumäe was split into several smaller lakes.

The second transition from peat to highly organic fine gyttja (in Punsu and Kõrbjärv) and reduced terrigenous input are consistent with the lake-level rise since $6500 \mathrm{BP}$. It is difficult to determine how long this increase lasted and how high the lake level was because there is no clear evidence available. We can only suggest that this rise could have lasted up to 5600-5200 BP. Later on, up to 3400 $\mathrm{BP}$, the lake level was rather low, but unstable. Between 3500-3000 BP, paludification intensified and, as a result, Lake Pedeja isolated. Since 3400 BP the lake level started to increase, being somewhat higher between 1800-800 BP. Radiocarbon dated and levelled peat from core 5 (Kirikumäe) reveals that $c .3200$ $\mathrm{BP}$ the lake level was about $3 \mathrm{~m}$, and about $2700 \mathrm{BP} 2-2.5 \mathrm{~m}$ lower than the present surface. Since that the lake level started to rise until it reached the present level. Both, climate and infiltration of the mire water to the lake are responsible for that rise.

\section{Climate reconstructions}

The climate reconstructions suggest a low, but unstable humidity and temperature in the early Pre-Boreal, some kind of stability in the late Pre-Boreal and early Boreal, a decrease in the late Boreal, and a sharp amelioration since $8200-8300$ BP. The background of this abrupt climate change is not yet clear. After an abrupt increase in temperature and precipitation in the late Boreal, the climate variations changed moderately. A significant temperature increase occurred in the late Atlantic and at the early Sub-Boreal/late Sub-Boreal transition. The temperature has dropped during the last millennia, with a major fall about 1000 $700 \mathrm{BP}$. The medieval warming and the Little Ice Age cooling are also traceable on the reconstructions. The precipitation value decreased during the late SubBoreal, being near its minimum about 3400, 2300-2400, 1300, and $800 \mathrm{BP}$, and higher than nowadays about 2200-1500, 1000-900, and $500 \mathrm{BP}$.

Comparison of the pollen based climate reconstructions with the lake-level records (which also indicate the moisture balance) shows a rather good coherent pattern of changes. Cold, severe climate with low precipitation values is consistent with the lake-level lowering in the early Pre-Boreal. During the climatic stability between 9500-8500 BP the lake level first increased, then stabilized, and finally decreased. The climate improvement since the middle Boreal, especially the humidity increase in the Atlantic, is also controlled by the lake-level rise. The decrease in precipitation and rather high summer temperatures could have caused an increase in evapotranspiration and reduction of water balance, what is also revealed in our lake-level reconstructions. This negative water balance trend changed about $3400-3200$ BP. Since then the July temperature 
decreased, the change of broad-leaved forest to coniferous one brought about reduced evapotranspiration. The reconstructed increase in precipitation between 2200-1500 and around $1000 \mathrm{BP}$ also coincides with the one reconstructed for the lake level about $1800-800 \mathrm{BP}$.

In the forest dynamics the most important changes took place in the PreBoreal. These include the establishment of the forest communities, the transition of pine/birch forest to broad-leaved forest in the late Boreal, and gradual demise of broad-leaved forest and re-establishment of pine/birch forest with spruce in the late Sub-Boreal.

\section{CONCLUSIONS}

1. Lake Kirikumäe with the neighbouring lakes could serve as a Holocene reference area in the Haanja Heights. The lake basin, formed as a result of the ice recession, at least in the Older Dryas, displays a sediment record since the Allerød.

2. The development of forests on the Haanja Heights was controlled by external factors, including climate, soils, hydrology, and human impact.

3. The Holocene vegetation history shows two major shifts. One occurred about $8500 \mathrm{BP}$, when a sharp decline in Betula-Pinus forest and development of the broad-leaved forest took place, and another about $3500 \mathrm{BP}$, when the broadleaved forest decreased and Pinus-Betula forest with a high share of Picea regenerated.

The specific features of the forests dynamics included:

(a) Picea immigration to the area in the Younger Dryas and its expansion during the Atlantic. In the Sub-Boreal and Sub-Atlantic periods spruce distribution had a fluctuating character and cannot therefore serve as a stratigraphical marker in the Sub-Boreal and Sub-Atlantic biostratigraphy (Kajak et al., 1976; Raukas et al., 1995).

(b) Ulmus immigrated at the end of the Pre-Boreal, Alnus about 400 years later.

(c) The dominance of the Quercetum mixtum forest with a high share of Tilia lasted throughout the early Sub-Boreal, which is considerably longer than elsewhere in Estonia. Tilia culminated in the early Sub-Boreal, not in the Atlantic.

(d) The expansion of Picea and Quercus was simultaneous.

4. The climatic reconstruction reflects one abrupt climatic change (amelioration) around $8500 \mathrm{BP}$ with several smaller fluctuations, including the Little Ice Age cooling.

5. The older radiocarbon dates of the surface samples may result from several factors, such as resedimentation, influx of old noncontemporaneous humic acid from the surrounding mire, especially during the lake-level regulation in the fifties. 
We thank A. Sarv for pollen analyses, T. Martma for $\delta^{13} \mathrm{C}$ analyses, and $\mathrm{M}$. Varvas for ${ }^{210} \mathrm{~Pb}$ measurements. Our thanks are also due to A. Raukas, A. Miidel, and R. Pirrus for discussions and comments, and to H. Kukk for linguistic revision of the manuscript. The financial support was received from the Estonian Science Foundation, grant No. 1958.

\section{REFERENCES}

Grimm, E. 1992. TILIA and TILIA graph: Pollen spreadsheet and graphics program. In 8 th International Palynological Congress. Abstracts. Aix-en-Provence, 56.

Eesti järved. 1968. Valgus, Tallinn.

Ilves, E. 1980a. Verzeichnis der im Institut für Zoologie und Botanik der Akademie der Wissenschaften der Estnischen SSR mittels der Radiokohlenstoff-Methode datierten Proben. Eesti NSV TA Toim. Biol., 29, 1, 73-79 (in Russian).

Ilves, E. 1980b. Tartu radiocarbon dates X. Radiocarbon, 22, 1084-1089.

Ilves, E. \& Mäemets, H. 1987. Results of radiocarbon and palynological analyses of coastal deposits of lakes Tuuljärv and Vaskna. In Palaeohydrology of the Temperate Zone, III. Mires and Lakes (Raukas, A. \& Saarse, L., eds.). Valgus, Tallinn, 108-130.

Ilves, E. \& Sarv, A. 1975. Dinamika rasseleniya eli v Estonii v poslelednikovoe vremya. In Sostojanie metodicheskikh issledovanij $v$ oblasti absoljutnoj khronologii. Moscow, 192198 (in Russian).

Kajak, K., Kessel, H., Liivrand, E., Pirrus, R., Raukas, A. \& Sarv, A. 1976. Stratigrafiya chetvertichnykh otlozhenij Estonii. In Stratigrafiya chetvertichnykh otlozhenij Pribaltiki (Vaitekunas, P. P. \& Gaigalas, A. J., eds.). Vilnius, $4-42$ (in Russian).

Moe, D. 1970. The Post-Glacial Immigration of Picea abies into Fennoscandia. Bot. Not., 123, 61-66.

Mäemets, A. 1977. Eesti NSV järved ja nende kaitse. Valgus, Tallinn.

Mäemets, H. 1983. Palynological and radiocarbon data on the postglacial vegetational history of Haanja Elevation (ESSR). In Man, Vegetation and Soil (Kurvits, J., ed.). Tartu, 98-111 (in Russian).

Mäemets, H. 1986. On palynological analysis of deposits from the banks of small lakes (after the example of Haanja Heights in the SE of Estonia). In Methods for the Investigation of Lake Deposits: Palaeoecological and Palaeoclimatological Aspects (Kabailiene, M., ed.). Vilnius, 46-48.

Orgla, K. 1983. The experience of using trend analysis for palaeobotanical reconstruction, exemplified by the spread of the spruce in NW East European Plain. In Palynologic Researches in Geologic Studies of the Baltic Region and the Baltic Sea (Bartosh, T., ed.). Zinatne, Riga, 18-23 (in Russian).

Pirrus, R. 1969. Stratigraphic division of South Estonian Late Glacial deposits by means of pollen analysis. Eesti NSV TA Toim. Keemia. Geol., 18, 2, 181-190 (in Russian).

Pirrus, R., Rõuk, A.-M. \& Liiva, A. 1987. Geology and stratigraphy of reference site of Lake Raigastvere in Saadjärve Drumlin Field. In Palaeohydrology of the Temperate Zone, II. Lakes (Raukas, A. \& Saarse, L., eds.). Valgus, Tallinn, 101-121.

Punning, J.-M., Koff, T., Ilomets, M. \& Jõgi, J. 1995. The relative influence of local, extra-local, and regional factors on organic sedimentation in the Vällamäe kettle hole, Estonia. Boreas, $24,1,65-80$. 
Rajamäe, R. \& Varvas, M. 1990. Sedimentation in some NE-Estonian lakes traced by ${ }^{210} \mathrm{~Pb}$ method. Freiberger Forschungshefte, C, 442, 126-135.

Raukas, A., Saarse, L. \& Veski, S. 1995. A new version of the Holocene stratigraphy in Estonia. Proc. Estonian Acad. Sci. Geol., 44, 4, 201-210.

Saarse, L. \& Königsson, L.-K. 1992. Holocene Environmental Changes on the Island of Saaremaa, Estonia. PACT, 37, 97-131.

Saarse, L., Veski, S., Rajamäe, R., Sarv, A. \& Heinsalu, A. 1990. Geology of Lake Maardu. Acad. Sci. ESSR, Tallinn. Preprint (in Russian).

Sarv, A. 1983. Stratigraphical subdivision of the Holocene bog and lacustrine deposits of the Remmeski and Senno sections. In Palynologic Researches in Geologic Studies of the Baltic Region and the Baltic Sea (Bartosh, T., ed.). Zinatne, Riga, 77-83 (in Russian).

Serebryanny, L. R. 1973. Rasprostranenie drevestnykh porod na Severo-Zapade SSSR v poslelednikovoe vremya. In Palinologiya golotsena $i$ marinopalinologiya. Moscow, 14-18 (in Russian).

Serebryanny, L. \& Raukas, A. 1967. Correlation of ice marginal belts in the Baltic Sea depression and the neighbouring countries. Baltica, 3, 235-249 (in Russian).

\title{
TAIMKATTE JA KLIIMA MUUTUSTEST HOLOTSEENIS HAANJA KÕRGUSTIKUL (KAGU-EESTI)
}

\author{
Leili SAARSE ja Raivo RAJAMÄE
}

Kirikumäe järv koos lähikonnas asuva Punsu ja Kõrbjärvega on valitud taimkatte looduslikku arengut kajastavaks tuumalaks Haanja kõrgustikul. Kirikumäe järve läbilõige katab jääajajärgsed viimased 12 000, Punsu oma 8000 ja Kõrbjärve oma vähemalt 8600 aastat. Et Punsu ja Kõrbjärves leidub märkimisväärses paksuses boreaalis ja atlantikumi esimesel poolel moodustunud turvast, sobivad need järved ka veetaseme kõikumise uurimiseks.

Allerødis levis siin metsatundra laadi taimkate kaseharvikute ja pajuga. Hilisdrüüases metsad taandusid põõsa-rohutundra tüüpi taimkatte ees, mis preboreaalis asendus juba peamiselt kasemetsaga. Holotseeni metsade arengus toimus kaks olulist muutust, esimene umbes 8500 aastat tagasi, kui männi-kasemetsad asendusid laialehiste metsadega, ja teine umbes 3500 aastat tagasi, kui taas said valdavaks männi-kase segametsad, paiguti kuusikud. Õietolmu andmetel põhinevad kliima rekonstruktsioonid näitavad kliima suhtelist jahedust preboreaalis ja boreaali esimesel poolel. Järsk kliima soojenemine toimus umbes 8500 aastat tagasi, mil tõusid nii temperatuur kui ka sademete hulk. Subboreaalis algas kliima kuivenemine ning alates ligi 3500 aastat tagasi ka temperatuuri langus. Selliste suurte kliimarütmide foonil joonistuvad välja ka väiksemad kõikumised, nagu kliima jahenemine nn. väikesel jääajal. Kliima rekonstruktsioone on võrreldud järvede veetaseme muutusega, mis samuti annab teavet kliima kuivuse või niiskuse kohta. 


\section{РАСТИТЕЛЬНОСТЬ И КЛИМАТ ГОЛОЦЕНА \\ НА ХААНЬЯСКОЙ ВОЗВЫШЕННОСТИ, ЮГО-ЗАПАДНАЯ ЭСТОНИЯ}

\section{Лейли СААРСЕ и Райво РАЯМЯЭ}

Для изучения этапов изменения растительности и климата голоцена на Хааньяской возвышенности были выбраны в качестве ключевых озера Кирикумяэ, Кырбъярв и Пунсу. Разрез оз. Кирикумяэ покрывает примерно 12000 лет, разрез оз. Кырбъярв - 8600 лет и разрез оз. Пунсу - 8000 лет.

Установлено, что в аллерёде растительность на Хааньяской возвышенности была схожа с лесотундровым типом, в верхнем дриасе стали превалировать пушицево-травянистые сообщества, в пребореале началось образование березово-сосновых лесов, которые в середине бореала сменились широколиственными породами. Новая смена растительности произошла примерно 3500 лет т. н., когда вновь стали доминировать березово-сосновые леса, но на этот раз с преобладанием ели.

Климатические реконструкции, основанные на результатах споровопыльцевых анализов, показали, что климат на Хааньяской возвышенности оставался довольно суровым еще в пребореале и первой половине бореала. Резкое потепление климата наступило примерно 8500 лет т. н. С тех пор климат голоцена не претерпевал сколько-нибудь резких изменений в ту или в иную сторону. С суббореала климат становился все суше, а с 3500 лет т. н. засушливый период чередовался с прохладными и влажными временными отрезками. На фоне общих, уже известных климатических реконструкций зарегистрирован целый ряд более мелких изменений, в том числе средневековое потепление и т. н. малая ледниковая эпоха.

Результаты изменений уровня воды в озерах, отражающих также влажность или сухость климата, довольно хорошо согласуются с реконструкциями, базирующимися на пыльцевой основе. 